\title{
MINORITIES AND WOMEN IN \\ THE PACIFIC SOCIOLOGICAL \\ ASSOCIATION REGION
}

A Five-Year Progress Report

\author{
STEPHEN KULIS \\ KAREN A. MILLER \\ MORRIS AXELROD \\ LEONARD GORDON \\ Arizona State University
}

Based on a five-year follow-up survey of sociology departments in the Pacific Sociological Association region, we report trends in the representation of women and minorities among faculty members and graduate students. Although men continue to predominate at all but the lecturer/instructor level, women are increasingly represented on faculties overall, in tenured positions, and among the higher academic ranks. Proportionally fewer men and women are now in entry level positions than in 1979. Except for Asians, minority faculty continue to be poorly represented. Women now make up the majority of graduate students at both the masters and doctoral levels, but both the proportion and number of minority students have declined in five years. Still, despite sharply contracting enrollment, both women and minority graduate students receive a larger share of financial assistance awards than they did five years ago.

In 1979, the Pacific Sociological Association sponsored a study of the sociology departments in the region to gather baseline data on the extent to which women and minority sociologists were represented in academic institutions (Nigg and Axelrod,

\footnotetext{
AUTHORS' NOTE: This study was funded, in part, by the Pacific Sociological Association, the American Sociological Association, the University of Oregon Center for Women in Society, and an Arizona State University support grant.
} 
1981). That study reported a larger proportion of women and minority faculty than earlier nationwide studies sponsored by the American Sociological Association had indicated, as well as proportionally more women and minority graduate students than had been found in prior years in the United States as a whole. Still, in the Pacific region in 1979, women and minorities were disproportionately concentrated at lower academic ranks, in nontenured positions, and in masters rather than doctoral programs. Overall, the proportions of minorities and women in faculty positions and in doctoral programs remained substantially lower than their proportions in the general population.

In this article, we compare the findings from the 1979 study with those from another survey undertaken five years later. In addition to describing the current proportional representation of women and minorities within a range of faculty and student positions, we explore institutional factors that may account for variations in the representation of these groups. We focus especially on changes in representation that have occurred over the last five years, and discuss apparent trends in the context of sharp contractions in faculty positions and in graduate student enrollment.

This report is both descriptive and analytic: It provides information that addresses the success of past efforts to incorporate women and minorities into academic sociology, documents the rate of change, and points to areas in which hiring, promotion, and admission practices may require further examination.

\section{METHODS}

Both the 1979 and 1984 surveys were conducted by the Survey Research Laboratory at Arizona State University, using parallel

We are especially grateful for the assistance rendered by Jean Stockard as Chair of the PSA Committee on the Status of Women in the Profession, and by Bettina Huber of the ASA Executive Office. The technical and analytical skills of Kathleen Fairman were also a major asset for this project. 
selection procedures and closely corresponding questionnaires. For the respective studies, the 1979 and 1984 editions of the ASA Directory of Sociology Departments were employed to identify four-year colleges or universities in 13 Pacific and Rocky Mountain states" that had either a sociology department or a "social science" department offering sociology courses. The 1979 survey identified 120 eligible departments, a number that increased to 147 in the 1984 survey. ${ }^{2}$ In order to ensure that apparent changes in representation from 1979 to 1984 are not simply attributable to the expansion of the population of departments in 1984, all of our reported findings have been confirmed for the departments that were respondents in both years. In assessing the statistical significance of trends and changes in the data from 1979 and 1984, it should be noted that each study comprised a nearly complete census, rather than sample, of the eligible populations of departments.

In the fall of 1979 and then the fall of 1984, questionnaires were mailed to the chairs of all eligible departments in the PSA region. With letters of endorsement from the presidents of the Pacific Sociological Association (1979 and 1984), and the American Sociological Association (1984), and with follow-up procedures, an overall response rate of $93 \%(\mathrm{~N}=111)$ was achieved in 1979 , and $91 \%(\mathrm{~N}=134)$ in 1984. Response rates were even higher for departments with graduate programs: $98 \%$ $(\mathrm{N}=56)$ in $1979,93 \%(\mathrm{~N}=51)$ in 1984 .

Chairs provided information on all of the sociologists within their departments, including adjunct and part-time faculty, reporting their sex, race or ethnicity, rank, tenure status, and committee responsibilities. For departments with graduate programs, chairs enumerated their graduate students by sex and race or ethnicity, both for all enrolled graduate students and separately for those graduate students receiving financial support in the form of scholarships, fellowships, assistantships, or associateships. 


\section{FINDINGS}

THE STATUS OF WOMEN FACULTY

\section{Academic Rank}

Among the women who hold sociology faculty positions, there is now somewhat less concentration in the lower ranks than was true in 1979 (see Table 1). Since 1979, the percentage of all women faculty who hold the rank of full professor has almost doubled; conversely, a lower percentage of the women are assistant professors now than in 1979. These findings reflect processes of promotion over time in a period of general contraction, that is, women have moved up the academic ladder, but fewer are entering the ladder at the bottom rung. This same pattern is evident for men, who have also become more concentrated in the upper academic ranks since 1979. As a consequence, men are still much more concentrated at the full professor level than women: $52 \%$ of male faculty and $27 \%$ of female faculty are full professors. To put in another way what Table 1 shows, women have improved in average rank since 1979, but women still hold considerably lower average rank than men.

Table 2 shows the percentage of all faculty who are women in sociology departments with graduate programs, by academic rank and year. Data for 1970 through 1972 are from the report of the American Sociological Association, The Status of Women in Sociology, 1968-72 (Hughes, 1973), and cover the entire nation. Data for 1979 and 1984 are from our study of the PSA region. Thus inferences about change between 1972 and 1979 must be considered only suggestive. Keeping that in mind, it appears that women have steadily increased their representation at all academic ranks except assistant professor. Between 1979 and 1984 , women have increased from $7 \%$ to $11 \%$ of all full professors in graduate departments in the PSA region. They now make up $24 \%$ of all associate professors, an increase from $20 \%$ in 1979. These gains, though slight, are encouraging. There is 
TABLE 1

Academic Rank of PSA Faculty Members in 1979, 1984, by Sex

\begin{tabular}{lrccc}
\hline & \multicolumn{2}{c}{1979} & \multicolumn{2}{c}{1984} \\
$\begin{array}{l}\text { ACADEMIC } \\
\text { RANR }\end{array}$ & MALE & FEMALE & MALE & F EMALE \\
\hline Professor & 40.1 & 14.9 & 51.7 & 27.0 \\
Associate Professor & 30.2 & 28.7 & 27.5 & 30.6 \\
Assistant Professor & 20.5 & 40.0 & 11.4 & 22.3 \\
Lecturer/Instructor & 4.6 & 9.8 & 2.5 & 13.7 \\
Other* & 4.6 & 6.6 & 6.9 & 6.5 \\
\multicolumn{1}{c}{ Total \& } & -50.08 & 100.08 & 100.08 & $100.1 \%$ \\
\multicolumn{1}{c}{ Total N } & 10073 & 275 & 997 & 278 \\
\hline
\end{tabular}

* Other ranks include emeriti, visiting, and adjunct professors.

TABLE 2

Percentage of Women Faculty in Sociology Departments with Graduate Programs by Academic Rank and Year

\begin{tabular}{|c|c|c|c|}
\hline ACADEMIC RANK & YEAR * & $\begin{array}{l}\text { PERCENT } \\
\text { FEMALE } \\
\text { FACULTY }\end{array}$ & $\begin{array}{l}\text { TOTAL } \\
\text { FACULTY }\end{array}$ \\
\hline Professor & $\begin{array}{l}1970 \\
1971 \\
1972 \\
1979 \\
1984\end{array}$ & $\begin{array}{r}4 \\
4 \\
5 \\
7 \\
11\end{array}$ & $\begin{array}{r}900 \\
1079 \\
1035 \\
361 \\
366\end{array}$ \\
\hline Associate Professor & $\begin{array}{l}1970 \\
1971 \\
1972 \\
1979 \\
1984\end{array}$ & $\begin{array}{l}10 \\
11 \\
12 \\
20 \\
24\end{array}$ & $\begin{array}{l}672 \\
744 \\
686 \\
272 \\
203\end{array}$ \\
\hline Assistant Professor & $\begin{array}{l}1970 \\
1971 \\
1972 \\
1979 \\
1984\end{array}$ & $\begin{array}{l}13 \\
12 \\
16 \\
35 \\
32\end{array}$ & $\begin{array}{r}996 \\
1163 \\
1115 \\
226 \\
98\end{array}$ \\
\hline Lecturer/Instructor & $\begin{array}{l}1970 \\
1971 \\
1972 \\
1979 \\
1984\end{array}$ & $\begin{array}{l}15 \\
25 \\
29 \\
40 \\
62\end{array}$ & $\begin{array}{r}288 \\
220 \\
190 \\
42 \\
39\end{array}$ \\
\hline
\end{tabular}

* Data for 1970-1972 are from the ASA's report, The Status of Women in Sociology: 1968-1972. Data for 1979 and 1984 are for the PSA region only. 
also a large leap in women's representation as lecturers and instructors, from $40 \%$ in 1979 to $62 \%$ in 1984 . This large percentage difference represents an increase of only a few cases, however, so its practical import may not be great. The drop from $35 \%$ of all assistant professors in 1979 to $32 \%$ in 1984 may, however, be of substantive concern; it may indicate that women are slightly less represented at the entry level than was the case in 1979. This appears to be a trend that should be monitored.

\section{Tenure Status}

Tenure status is perhaps the most crucial criterion for continuing a career in academe. It is closely related to, but not determined by, academic rank. Table 3 shows that since 1979 increasing proportions of both sexes are tenured, about $10 \%$ more for each sex now than in 1979. This suggests that men and women are being tenured at approximately equal rates. It also means that, as in 1979 , a higher proportion of men than women are tenured: $81 \%$ of men compared to $56 \%$ of women. Compared to 1979 , smaller proportions of men and women are now in tenure-track positions, suggesting the contraction of hiring for both sexes. Proportions of men and women faculty in nontenure-track positions are similar to the proportions in 1979. All of this confirms the conclusion that women have made some gains but are still disadvantaged relative to men in terms of security and rank of their academic jobs.

\section{Institutional Variations}

Certain institutional factors are implicated in women's proportional representation, and in their attainment of higher academic rank and tenure. In 1979 the distribution of men and women was quite similar in departments with and without graduate programs, and in Rocky Mountain and Pacific coastal states, but differences emerged in 1984. The proportion of women faculty is now higher in departments without graduate programs 
TABLE 3

Tenure Status of Faculty Members in the PSA Region by Sex

\begin{tabular}{|c|c|c|c|c|}
\hline \multirow{2}{*}{$\begin{array}{l}\text { TENURE } \\
\text { STATUS }\end{array}$} & \multicolumn{2}{|c|}{1979} & \multicolumn{2}{|c|}{1984} \\
\hline & MALE & FEMALE & MALE & F EMALE \\
\hline Tenured & 71.8 & 44.4 & 81.1 & 56.2 \\
\hline Not Tenured & 18.2 & 34.2 & 10.0 & 21.2 \\
\hline Not on a Tenure Track & 10.0 & 21.4 & $\begin{array}{r}8.9 \\
-\end{array}$ & 22.6 \\
\hline Total & 100.08 & 100.08 & 100.08 & 100.08 \\
\hline Total N & 1063 & 266 & 963 & 274 \\
\hline
\end{tabular}

$(24 \%)$ than in those with them $(20 \%)$. At the same time, there is a higher percentage of women on faculties in states on the Pacific (23\%) than in the mountain states $(18 \%)$. Further, women in 1984 occupied higher average rank in departments without graduate programs than in those with graduate programs, whereas the reverse was true for men.

Other institutional differences appeared in both 1979 and 1984, with women making up a larger portion of the faculties in private institutions, and in those institutions with small student bodies, although by 1984 the differences in female representation had become less pronounced. In 1984 women constituted $20 \%$ of the sociology faculties in publicly sponsored schools, $23 \%$ in religiously affiliated, and $28 \%$ in secular private schools. Proportionally, there were somewhat more women in institutions with enrollments under $2000(25 \%)$ than in larger schools $(21 \%)$. In 1979 women who were disproportionately concentrated in small, private institutions were twice as likely to be tenured as the women in public schools. The reverse occurred in 1984, with women (and men) more likely to be tenured in public than in private institutions, and, within private institutions, more likely to be tenured in those with larger student bodies.

In contrast to the portrayal in 1979 , women in small, private institutions do not seem to be in more secure positions in 1984 
than those in public institutions. Relative to their male counterparts, in 1984 the percentage of women in higher academic ranks and in tenured positions was higher in public than in private institutions. Tenure rates for women lagged farthest behind men in secular private institutions. Geography also played a role, with more pronounced male-female differences in rank and tenure in departments in Rocky Mountain states than in those bordering the Pacific Ocean.

\section{Committee Responsibilities}

Results from 1979 suggested that women may have become "overloaded" with committee assignments, draining their available time and energy from research and writing, and perhaps diminishing their prospects for attaining tenure. When men and women with the same tenure status were compared, women faculty were consistently found to be serving on more standing departmental, college, or university committees. Untenured women in particular appeared to be shouldering an exceptionally large load of committee duties, with nearly half on three or more committees. These results, in part, led to a recommendation from the PSA leadership that chairs guard against overloading women and minority faculty with committee responsibilities.

The distribution, five years later, of committee duties appears to have shifted for women (Table 4), although because of the large amount of missing data we should interpret the results with caution. ${ }^{3}$ Whereas the typical committee responsibilities of tenured men have changed very little since 1979 , women at each tenure status are now generally serving on fewer committees than they did in 1979. With two exceptions, the number of committee assignments of men and women now roughly correspond. The committee duties of untenured women have declined markedly from 1979 levels, and are now numerically "lighter" than those of their male counterparts; tenured women still serve on slightly more committees than tenured men. It appears that progress has been made in allowing untenured women to 
TABLE 4

Number of Committee Assignments of Sociology Faculty in 1979 and $1984^{\mathrm{a}}$ by Sex and Tenure Status

\begin{tabular}{|c|c|c|c|c|c|c|}
\hline \multirow[b]{3}{*}{$\begin{array}{l}\text { NUMBER OF } \\
\text { COMMITTEES }\end{array}$} & \multicolumn{6}{|c|}{ TENURE STATUS OF WOMEN } \\
\hline & \multicolumn{2}{|c|}{$\begin{array}{c}\text { NOT } \\
\text { TENURE-TRACK }\end{array}$} & \multicolumn{2}{|c|}{$\begin{array}{c}\text { NOT } \\
\text { TENURED }\end{array}$} & \multicolumn{2}{|c|}{ TENU RED } \\
\hline & 1979 & 1984 & 1979 & 1984 & 1979 & 1984 \\
\hline None & 66.7 & 73.8 & 10.0 & 12.5 & 14.9 & 13.0 \\
\hline One & 17.9 & 9.5 & 12.5 & 28.1 & 23.4 & 9.8 \\
\hline Two & 10.3 & 2.4 & 30.0 & 31.3 & 8.5 & 26.1 \\
\hline Three or more & 5.1 & 14.3 & 47.5 & 28.1 & 53.2 & 51.1 \\
\hline Total & 100.08 & 100.08 & 100.08 & $100.0 \%$ & 100.08 & 100.08 \\
\hline Total N & 39 & 42 & 40 & 32 & 47 & 92 \\
\hline
\end{tabular}

TENURE STATUS OF MEN

\begin{tabular}{|c|c|c|c|c|c|c|}
\hline \multirow[b]{2}{*}{$\begin{array}{l}\text { NU MB ER OF } \\
\text { COMMI TTEES }\end{array}$} & \multicolumn{2}{|c|}{$\begin{array}{c}\text { NOT } \\
\text { TENURE-TRACK }\end{array}$} & \multicolumn{2}{|c|}{$\begin{array}{c}\text { NOT } \\
\text { TENURED }\end{array}$} & \multicolumn{2}{|c|}{ TENURED } \\
\hline & 1979 & 1984 & 1979 & 1984 & 1979 & 1984 \\
\hline None & 81.2 & 76.5 & 11.1 & 17.0 & 9.9 & 14.4 \\
\hline One & 11.6 & 11.8 & 31.9 & 13.6 & 25.5 & 18.0 \\
\hline Two & 5.8 & 0.0 & 29.2 & 25.4 & 25.2 & 22.5 \\
\hline Three or more & 1.4 & 11.8 & 27.8 & 44.1 & 39.4 & 45.1 \\
\hline Total & 100.08 & $100.1 \%$ & 100.08 & $100.1 \%$ & 100.08 & 100.08 \\
\hline Total $\mathrm{N}$ & 69 & 51 & 72 & 59 & 345 & 417 \\
\hline
\end{tabular}

a. Excluding chairs and other administrators.

avoid conflicts between organizational responsibilities and scholarly pursuits.

\section{Leadership Roles}

Historically, women have not been prominent as chairs of departments of sociology, occupying these leadership roles in 
even fewer numbers than their proportional representation on faculties would suggest. In 1971 , only $6 \%$ of the chairs of graduate programs were women (Jackson, 1972). By 1979, some improvement was suggested in the PSA region, when $15 \%$ of the chairs were women, compared to the $20 \%$ of faculty members who were women. In 1984, the proportion of women faculty increased to $22 \%$ whereas the proportion of women chairs in the PSA region declined to $12 \%$. This apparent underrepresentation can be attributed to the fact that women are less likely than men to be full professors, from whom department chairs are usually, although not always, drawn. Because only $13 \%$ of full professors in the PSA are now women, the proportion of chairs who are women closely reflects the pool of eligible women for these positions. Moreover, women chairs are now more evident in departments with graduate programs $(15 \%)$ than in those without them $(7 \%)$.

\section{THE STATUS OF RACIAL AND}

ETHNIC MINORITY FACULTY

The change from 1979 to 1984 in the status of racial and ethnic minorities is similar in some ways to the change observed for women, but for most ethnic groups the trend is even less encouraging than the trend for women. In Table 5, the total numbers of cases show to some extent the contraction in the field we observed when looking at gender. Compared to five years ago, there are now fewer blacks and Asians, but more Mexican Americans, and no change in the small number of other Hispanics in the PSA region. There are only three Native American faculty members in the PSA region, a number too small to show meaningfully in the table, but we note here that one is a full professor, one an associate professor, and another an assistant professor. It should be kept in mind throughout this discussion that the number of cases for all minority groups is very small, and that substantial changes in percentages may represent small differences in actual numbers of people.

Table 5 shows that, except for Hispanics other than Mexican Americans, there has been a marked increase in the proportions 
TABLE 5

Academic Rank of Faculty by Race or Ethnicity in 1979 and 1984

\begin{tabular}{|c|c|c|c|c|c|c|c|c|c|c|}
\hline \multirow{3}{*}{$\begin{array}{l}\text { ACADEMIC } \\
\text { RANK }\end{array}$} & \multicolumn{4}{|c|}{ RACE OR } & \multicolumn{2}{|c|}{ ETHNICITY } & & & & \\
\hline & \multicolumn{2}{|c|}{ WH ITE } & \multicolumn{2}{|c|}{ BLACX } & \multicolumn{2}{|c|}{$\begin{array}{l}\text { MEXICAN } \\
\text { AMERI CAN }\end{array}$} & \multicolumn{2}{|c|}{$\begin{array}{l}\text { OTHER } \\
\text { HIS PANI C }\end{array}$} & \multicolumn{2}{|c|}{ ASIAN } \\
\hline & 1979 & 1984 & 1979 & 1984 & 1979 & 1984 & 1979 & 1984 & 1979 & 1984 \\
\hline Prof. & 36.2 & 46.8 & 13.1 & 40.0 & 5.6 & 18.5 & 43.8 & 43.8 & 37.9 & 55.9 \\
\hline Assoc. & 30.1 & 28.1 & 39.1 & 20.0 & 22.2 & 33.3 & 18.8 & 31.3 & 27.3 & 25.4 \\
\hline Assist. & 23.7 & 13.0 & 32.6 & 28.6 & 44.4 & 37.0 & 25.0 & 12.5 & 21.2 & 10.2 \\
\hline Lec/Ins. & 5.1 & 5.1 & 8.7 & 8.6 & 22.2 & 3.7 & 6.2 & 6.3 & 7.6 & 1.7 \\
\hline Other & 4.9 & 7.0 & 6.5 & 2.9 & 5.6 & 7.4 & 6.2 & 6.3 & 6.0 & 6.8 \\
\hline Total & 100.0 & 100.0 & 100.0 & 100.1 & 100.0 & 99.9 & 100.0 & 100.2 & 100.0 & 100.0 \\
\hline Total N & 1168 & 1122 & 46 & 35 & 18 & 27 & 16 & 16 & 66 & 59 \\
\hline
\end{tabular}

of all minorities who are full professors. For Hispanics other than Mexican Americans, there has been essentially no change in the proportion who are full professors. For all groups there is a decrease in the proportions in entry level (assistant professor) positions. This suggests that for most minorities, the general trend we have noted holds true: Those already in the system have tended to be promoted, but fewer new people are entering the tenure track.

We next examine, in Table 6 , the change in the status of minorities as a proportion of all faculty in the PSA sociology departments with graduate programs, comparing it to national trend data from the early 1970s from the ASA report on "The Status of Racial and Ethnic Minorities"' (Blackwell et al., 1977). ${ }^{4}$ In Table 6 we are struck first of all by the tiny percentages of all faculty who are minorities. This is certainly still true, but has there been any progress? Blacks, for example, make up $2.5 \%$ of all full professors whereas five years ago they were $1.7 \%$, a small gain. They show a declining proportion at the associate level, but a gain at the assistant level after five years. Hispanics and Asians show small gains at the full professor level, but a 
TABLE 6

Percentage of Minority Faculty in Sociology Departments with Graduate Programs by Academic Rank and Year

\begin{tabular}{|c|c|c|c|c|c|c|c|}
\hline \multirow[b]{2}{*}{$\begin{array}{l}\text { ACADEMIC } \\
\text { RANK }\end{array}$} & \multicolumn{7}{|c|}{ RACE OR ETHNICITY } \\
\hline & YEAR * & B LAACR & $\begin{array}{l}\text { SPANISH } \\
\text { ALL } \\
\text { HISPAN IC }\end{array}$ & $\begin{array}{l}\text { MERICAN } \\
\text { MEXI CAN- } \\
\text { AMERICAN }\end{array}$ & $\begin{array}{c}\text { NATIVE } \\
\text { AMERICAN }\end{array}$ & ASIAN & $\begin{array}{c}\text { NUMB ER } \\
\text { OF } \\
\text { CASES }\end{array}$ \\
\hline Professor & $\begin{array}{l}1970 \\
1972 \\
1974 \\
1979 \\
1984\end{array}$ & $\begin{array}{l}2.0 \\
1.9 \\
2.6 \\
1.7 \\
2.5\end{array}$ & $\begin{array}{l}\star \star \\
0.2 \\
0.5 \\
1.4 \\
1.9\end{array}$ & $\begin{array}{l}(0.0) \\
(0.6)\end{array}$ & $\begin{array}{l}\star \star \\
0.2 \\
0.0 \\
0.0 \\
0.0\end{array}$ & $\begin{array}{l}\star \star \\
1.1 \\
0.3 \\
5.3 \\
5.8\end{array}$ & $\begin{array}{r}900 \\
1029 \\
1028 \\
358 \\
365\end{array}$ \\
\hline $\begin{array}{l}\text { Associate } \\
\text { Professor }\end{array}$ & $\begin{array}{l}1970 \\
1972 \\
1974 \\
1979 \\
1984\end{array}$ & $\begin{array}{l}3.0 \\
2.8 \\
4.1 \\
5.2 \\
3.0\end{array}$ & $\begin{array}{l}\star \star \\
0.5 \\
1.5 \\
2.2 \\
3.0\end{array}$ & $\begin{array}{l}(1.5) \\
(2.0)\end{array}$ & $\begin{array}{l}\star * \\
0.5 \\
0.0 \\
0.0 \\
0.0\end{array}$ & $\begin{array}{r}\star \star \\
1.4 \\
2.3 \\
4.4 \\
4.4\end{array}$ & $\begin{array}{l}672 \\
647 \\
748 \\
271 \\
203\end{array}$ \\
\hline $\begin{array}{l}\text { Assistant } \\
\text { Professor }\end{array}$ & $\begin{array}{l}1970 \\
1972 \\
1974 \\
1979 \\
1984\end{array}$ & $\begin{array}{l}2.0 \\
2.9 \\
4.5 \\
4.9 \\
6.2\end{array}$ & $\begin{array}{l}\star * \\
0.5 \\
1.1 \\
5.4 \\
5.2\end{array}$ & $\left(\begin{array}{l}3.6) \\
(5.2)\end{array}\right.$ & $\begin{array}{r}\star \star \\
1.0 \\
0.5 \\
0.4 \\
1.0\end{array}$ & $\begin{array}{l}\star \star \\
2.1 \\
2.7 \\
4.4 \\
3.1\end{array}$ & $\begin{array}{r}996 \\
1024 \\
1171 \\
225 \\
97\end{array}$ \\
\hline $\begin{array}{l}\text { Lecturer/ } \\
\text { Instructor }\end{array}$ & $\begin{array}{l}1970 \\
1972 \\
1974 \\
1979 \\
1984\end{array}$ & $\begin{array}{r}7.6 \\
16.3 \\
11.2 \\
4.8 \\
5.1\end{array}$ & $\begin{array}{l}\star \star \\
1.7 \\
1.3 \\
9.5 \\
0.0\end{array}$ & $\begin{array}{l}(7.1) \\
(0.0)\end{array}$ & $\begin{array}{l}\star \star \\
2.8 \\
0.0 \\
0.0 \\
0.0\end{array}$ & $\begin{array}{l}\star \star \\
0.0 \\
0.7 \\
4.8 \\
0.0\end{array}$ & $\begin{array}{r}288 \\
178 \\
543 \\
42 \\
39\end{array}$ \\
\hline
\end{tabular}

* Data for 1970, 1972, and 1974 come from the American Sociological Association's Report on The Status of Racial and Ethnic Minorities in Sociology, which appears in a Footnotes Special Supplement in August 1977. Data for 1979 and 1984 are for the PSA region only.

** Minorities other than blacks were not included in the 1970 audit of graduate departments of sociology.

loss at the assistant and lecturer level. The picture is thus mixed, with slight gains at the upper ranks counterbalanced by slight losses at the lower ranks.

With respect to tenure status, Table 7 shows that every ethnic group in the PSA region has become more "top heavy." That is, there is an increase in the proportions within each group who are tenured, and decreases in those on a tenure track but not yet tenured. For all groups except blacks, there is also a decrease in the proportion who are not in tenure-track positions. 
TABLE 7

Tenure Status of Faculty Members in the PSA Region by Race or Ethnicity

\begin{tabular}{|c|c|c|c|c|c|c|c|c|c|c|}
\hline \multirow{2}{*}{$\begin{array}{l}\text { TENURE } \\
\text { STATUS }\end{array}$} & \multicolumn{2}{|c|}{ WHITE } & \multicolumn{2}{|c|}{ BLACR } & \multicolumn{2}{|c|}{$\begin{array}{l}\text { MEXI CAN } \\
\text { AMERICAN }\end{array}$} & \multicolumn{2}{|c|}{$\begin{array}{c}\text { OTHER } \\
\text { H ISPANIC }\end{array}$} & \multicolumn{2}{|c|}{ ASIAN } \\
\hline & 1979 & 1984 & 1979 & 1984 & 1979 & 1984 & 1979 & 1984 & 1979 & 1984 \\
\hline Tenured & 67.4 & 76.8 & 54.5 & 62.9 & 33.3 & 48.2 & 50.0 & 75.0 & 67.6 & 76.3 \\
\hline $\begin{array}{l}\text { Not } \\
\text { Tenured }\end{array}$ & 20.4 & 11.3 & 36.4 & 22.9 & 44.5 & 40.7 & 31.3 & 18.8 & 16.9 & 10.2 \\
\hline $\begin{array}{l}\text { Not on } \\
\text { Tenure } \\
\text { Track }\end{array}$ & 12.2 & 11.9 & 9.1 & 14.3 & 22.2 & 11.1 & 18.7 & 6.3 & 15.4 & 13.6 \\
\hline Total & 100.0 & 100.0 & 100.0 & 100.1 & 100.0 & 100.0 & 100.0 & 100.1 & 99.9 & 100.1 \\
\hline Total N & 1152 & 1085 & 44 & 35 & 18 & 27 & 16 & 16 & 65 & 59 \\
\hline
\end{tabular}

The presence and distribution of minorities depends to a limited degree on regional and institutional factors. The portion of faculty who are minorities is higher in schools with enrollments under $2000(15 \%)$ than in larger schools $(11 \%)$, but the proportions of minority faculty are not related to the size of the departmental faculty nor to the auspices (public, private, or religious) of the institution. Except for Hispanics, minorities are highly concentrated in Pacific coastal rather than in Rocky Mountain states. Although the numbers are very small, there appears to be some differentiation among minority groups. Whereas the majority of Asian and black faculty members are in departments with graduate programs, most Hispanics and Native Americans are in nongraduate departments. Further, whereas $13 \%$ of departmental chairs in 1984 are minorities (a proportion that reflects their representation among faculty members far better than does the proportion of women chairs), two-thirds of these minority chairs are Asian.

\section{Minority Women}

Given the underrepresentation of women and minorities on sociology faculties in the PSA region, small numbers of 
minority women would not be surprising. The percentage found in $1984(1.4 \%)$, however, is substantially less than the joint proportions of women and minorities would lead us to expect. Of the 18 minority women in the PSA, the majority are either Asian $(44 \%)$ or black $(33 \%)$. Only $7 \%$ of women faculty are minorities, but $13 \%$ of male faculty are minorities. The severe underrepresentation of minority women may be perpetuated by their relatively lower probability of being tenured. The proportion of faculty with tenure is $50 \%$ for minority women, $57 \%$ for white women, $70 \%$ for minority men, and $83 \%$ for white men. In obtaining a tenured position, being a woman is apparently more of a disadvantage than being a member of an ethnic or racial minority group. In combination, these two statuses appear to limit the attainment of job security severely.

\section{GRADUATE STUDENTS IN SOCIOLOGY}

\section{Women Graduate Students}

In contrast to their minority position on faculties, where they now number only $22 \%$ of all faculty members, women constitute a slowly growing majority among the ranks of sociology graduate students (Table 8). In 1979 graduate students were divided almost equally between men and women, but women now make up $54 \%$ of all graduate students in the Pacific region. Moreover, women are increasingly likely to be enrolled in both masters and doctoral programs in sociology (Table 9). National data from the late 1960s and early 1970 s indicated that women were then a clear minority among sociology graduate students, and particularly among doctoral students. In the PSA region, by 1979 women not only achieved parity of representation with men overall but the gap between their representation in masters and doctoral programs narrowed considerably. This same trend continued into 1984, with women now numbering more than half of both masters and Ph.D. students. The increasing proportions of female doctoral students indicate that, at least numerically, women will 


\section{TABLE 8}

Distribution of Sex and Race or Ethnicity for All Graduate Students and for those Graduate Students Receiving Financial Support

\begin{tabular}{|c|c|c|c|c|}
\hline & \multicolumn{2}{|c|}{ ALL STUDENTS } & \multirow{2}{*}{$\begin{array}{c}\text { SUPPORTED } \\
1979\end{array}$} & \multirow{2}{*}{$\begin{array}{c}\text { STUDENTS } \\
1984\end{array}$} \\
\hline & 1979 & 1984 & & \\
\hline \multicolumn{5}{|l|}{ SEX } \\
\hline Female & 49.8 & 53.8 & 54.4 & 53.2 \\
\hline Male & 50.2 & 46.2 & 45.6 & 46.8 \\
\hline Total & 100.08 & 100.08 & 100.08 & 100.08 \\
\hline Total N & 2016 & 1326 & 763 & 701 \\
\hline \multicolumn{5}{|l|}{ RACE OR ETHNICITY* } \\
\hline White/Anglo & 79.6 & 78.1 & 80.9 & 72.8 \\
\hline $\mathrm{Bl}$ ack & 6.4 & 4.2 & 4.8 & 6.4 \\
\hline Mexican-American & 4.3 & 5.3 & 4.7 & 5.1 \\
\hline Other Hispanic & 1.4 & 1.2 & 0.7 & 1.2 \\
\hline Asian/Oriental & 7.5 & 10.0 & 7.9 & 12.1 \\
\hline Native American & 0.7 & 0.9 & 1.0 & 1.3 \\
\hline Other & 0.1 & 0.2 & 0.0 & 1.0 \\
\hline Total & 100.08 & 99.98 & 100.08 & 99.98 \\
\hline Total N & 2016 & 1280 & 763 & 670 \\
\hline
\end{tabular}

* Race or ethnicity of 46 international students was not identified; they have been excluded from this portion of the table.

be better positioned within the pool from which future faculty members are drawn.

\section{Minority Graduate Students}

As in 1979, racial and ethnic minorities are also better represented, proportionally, among graduate students than among faculty members in sociology (Table 8 ). Like the growing representation of women students, the proportion of students who are minorities increased from $20 \%$ to $22 \%$ between 1979 
TABLE 9

Percentage of Females in Graduate Programs

by Year and Degree Sought

\begin{tabular}{|c|c|c|c|c|}
\hline YEAR * & M.A. & $\begin{array}{l}\text { PERCENT OF } \\
\text { PROGRAMS }\end{array}$ & $\begin{array}{c}\text { FEMAL ES } \\
\text { PH.D. }\end{array}$ & $\begin{array}{l}\text { IN : } \\
\text { PROGRAMS }\end{array}$ \\
\hline 1969 & & 37 & & 30 \\
\hline 1972 & & 37 & & 24 \\
\hline 1979 & & 53 & & 48 \\
\hline 1984 & & 54 & & 54 \\
\hline
\end{tabular}

*Data for 1969 are from Rossl (1970), and for 1972, from the ASA's report on The Status of Women in Sociology: 1960-1972. Data for 1979 and 1984 are for the PSA region only.

and 1984. In the same period minorities made up around $11 \%$ to $12 \%$ of faculty members. Asians now constitute the largest single group of minority students, as they did in 1979. In 1979 Asians were followed closely by blacks, but are now more distantly followed by Mexican Americans. Of the three largest minority groups, Asian representation among graduate students has increased, and black representation has decreased by a similar margin, whereas Hispanic representation has expanded only slightly in five years.

\section{Financial Support}

Financial support is undoubtedly a major factor in the decision to embark upon and continue a graduate school career. In addition to defraying the costs of tuition, this support may provide for living expenses and introduce students to the teaching and research experiences of the faculty. Limited opportunities for financial support, and any inequities in its distribution, may discourage students from pursuing advanced degrees in sociology. 
For economically disadvantaged minorities, this financial support would presumably be especially crucial for a graduate career.

In 1979 , all minorities together made up $20 \%$ of all graduate students, and $19 \%$ of the students receiving financial support (Table 8). Mexican American and Asian students received a share of financial support awards that mirrored their proportional representation among all graduate students. Blacks in 1979 were only slightly less likely to be represented among supported students than among all students.

In 1984, except for Hispanics, minority representation among the ranks of supported graduate students exceeded their proportional representation among all graduate students. Numbering only $22 \%$ of the graduate student body, minorities constituted $27 \%$ of the students receiving financial support. This represents a significant shift since 1979. Blacks and Asians appear to be the groups whose share of financial support has increased the most in five years relative to their total enrollments.

Although the percentage differences shown in Table 8 for financial support are small when measured relative to the total populations of students, Table 10 indicates that from 1979 to 1984 the likelihood of receiving financial support actually increased markedly for minority students. In 1979 only about one in three minority students received financial support, and their chances were slightly poorer than for white students. By 1984 the proportion of white students receiving financial support increased modestly, from $38 \%$ to $49 \%$, but the proportion of minorities receiving support nearly doubled, from $36 \%$ to $65 \%$. Certain minority students five years ago-Mexicans, Asians, and Native Americans-were somewhat more likely than whites to be supported, but now this is true for all minorities. The dramatic increase in the percentage of black graduate students receiving financial support, from $29 \%$ to $80 \%$, is especially notable.

For women graduate students, the percentage receiving financial support has also increased, from $41 \%$ to $52 \%$ over the period 1979 to 1984 . During this time, however, the proportion of male graduate students receiving support has increased even more dramatically, from about one-third to over one-half. In 1984 
TABLE 10

Percentage of Graduate Students Receiving Support, and Change in Graduate Enrollment, 1979-1984, by Sex and Race or Ethnicity

\begin{tabular}{|c|c|c|c|c|c|}
\hline & \multicolumn{2}{|c|}{$\begin{array}{c}\text { PERCENT } \\
\text { SUPPORTED }\end{array}$} & \multicolumn{2}{|c|}{$\begin{array}{c}\text { TOTAL } \\
\text { ENROLLMENT }\end{array}$} & \multirow{2}{*}{$\begin{array}{l}\text { PERCENT } \\
\text { CAANGE DN } \\
\text { ENROLLMENT } \\
(1979-1984)\end{array}$} \\
\hline & $\begin{array}{r}\text { PSA } \\
1979\end{array}$ & $\begin{array}{r}\text { PSA } \\
1984\end{array}$ & $\begin{array}{r}\text { PSA } \\
1979\end{array}$ & $\begin{array}{r}\text { PSA } \\
1984\end{array}$ & \\
\hline \multicolumn{6}{|l|}{ SEX } \\
\hline Female & 41.3 & 52.3 & 1004 & 713 & -29.0 \\
\hline Male & 34.3 & 53.5 & 1012 & 613 & -39.4 \\
\hline \multicolumn{6}{|l|}{ RACE OR ETHNICITY* } \\
\hline White/Anglo & 38.4 & 48.8 & 1605 & 1000 & -37.7 \\
\hline Bl ack & 28.7 & 79.6 & 129 & 54 & -58.1 \\
\hline Mexican-American & 41.4 & 50.0 & 87 & 68 & -21.8 \\
\hline Other Hispanic & 17.9 & 53.3 & 28 & 15 & -46.4 \\
\hline Asian/oriental & 39.7 & 63.3 & 151 & 128 & -15.2 \\
\hline Native American & 57.1 & 75.0 & 14 & 12 & -14.3 \\
\hline
\end{tabular}

* Race or ethnjcity of 46 international students was not identified; they have been excluded from this portion of the table.

virtually equal proportions of male and female graduate students were supported.

The proportion of students receiving financial support has increased for all sex, ethnic, and racial categories, but these figures do not necessarily indicate that opportunities for support have expanded. In fact, these opportunities have declined by $12 \%$ in the PSA region, ${ }^{5}$ from 763 supported graduate students in 1979 to 670 in 1984 . To some extent the increasing proportion of students who receive support reflects sharp decreases in total graduate enrollment, which has dropped substantially in five years for every sex, ethnic, and racial category, as shown in Table 10. In percentage terms, the decline in enrollment has been most pronounced among blacks and non-Mexican Hispanics, the two groups exhibiting the largest increases in the 
proportions of students receiving financial support. There were only six more blacks receiving financial support in 1984 than in 1979, a $16 \%$ increase, while the total number of enrolled black students has decreased by more than half in the same period.

Overall, it appears that as academic employment and graduate enrollment in the profession have contracted over the last five years, the number of minorities receiving financial support has increased very slightly, but the proportion receiving support has increased dramatically. Perhaps of general concern to the profession, the data for all groups can also be read to indicate that over the last five years, a graduate career without financial support has become far more uncommon, and perhaps more unattractive or untenable, particularly for blacks and nonMexican Hispanics, and more so for men than for women. Although our data cannot address the reasons for the dramatically declining numbers of unsupported graduate students, we may be witnessing a trend toward only the supported pursuing and surviving graduate education in sociology. Despite this contraction, the share of financial support going to women and minorities has grown.

\section{CAREER STATUS OF PSA SOCIOLOGISTS}

Our final two tables provide snapshots of trends in the inclusion of women and ethnic or racial minorities across several stages of an academic career. Table 11 indicates that women predominate at the earliest stages of preparation for a career in sociology, and that the proportional representation of women declines at every subsequent step up the career ladder. Women are still noticeably uncommon among the ranks of tenured faculty members. Still, there are two encouraging signs. There was a modest but steady increase in female representation from 1979 to 1984 , and women now outnumber men among the graduate students from whom future faculty will presumably be drawn.

For minorities (Table 12) the outlook is mixed at best. The predominance of whites among faculty members is virtually unchanged from 1979 to 1984. Moreover, although minority 
TABLE 11

Sex by the Career Status of Sociologists in the PSA Region in 1979 and 1984

\begin{tabular}{|c|c|c|c|c|c|c|c|c|}
\hline \multirow{3}{*}{ SEX } & \multicolumn{8}{|c|}{ CAREER STATUS } \\
\hline & \multicolumn{2}{|c|}{$\begin{array}{l}\text { MASTER } \\
\text { STUDENTS }\end{array}$} & \multicolumn{2}{|c|}{$\begin{array}{l}\text { DOCTORAL } \\
\text { STUDENTS }\end{array}$} & \multicolumn{2}{|c|}{$\begin{array}{l}\text { UNTENURED } \\
\text { FACULTY }\end{array}$} & \multicolumn{2}{|c|}{$\begin{array}{l}\text { TENURED } \\
\text { FACULTY }\end{array}$} \\
\hline & 1979 & 1984 & 1979 & 1984 & 1979 & 1984 & 1979 & 1984 \\
\hline Female & 53.3 & 53.9 & 47.5 & 53.7 & 33.0 & 39.7 & 13.4 & 16.5 \\
\hline Male & $\begin{array}{l}46.7 \\
-\end{array}$ & $\begin{array}{r}46.1 \\
-\cdots\end{array}$ & 52.5 & 46.3 & 67.0 & 60.3 & 86.6 & $\begin{array}{l}83.5 \\
--.-\end{array}$ \\
\hline Total & 100.08 & 100.08 & 100.08 & 100.08 & 100.08 & 100.08 & 100.08 & 100.08 \\
\hline Total N & 801 & 553 & 1215 & 773 & 448 & 302 & 881 & 935 \\
\hline
\end{tabular}

representation has increased at the doctoral student level, it has decreased by a similar margin at the masters level, and the pool of potential minority faculty may not be appreciably increasing. Further, the trend for blacks at all levels is toward decreased representation. Although it may be a positive reflection on the profession that minority students now receive an enhanced share of opportunities for financial support, there is no evidence that these efforts, as yet, have brought either greater numbers or a significantly greater proportion of minorities into the profession.

\section{DISCUSSION}

The findings of this study, which chart the shifting proportions of women and minorities within academic sociology, reflect a complex process of individual, departmental, and institutional decisions, all of which take place in larger social, political, and economic contexts. We can neither conclude that increases in the proportional representation of women signify successful affirmative action policies nor that the relatively unchanging pro- 
TABLE 12

Race or Ethnicity by the Career Status of Sociologists in the PSA Region in 1979 and 1984

\begin{tabular}{|c|c|c|c|c|c|c|c|c|}
\hline \multirow{3}{*}{$\begin{array}{l}\text { RACE OR } \\
\text { EIH NICITY* }\end{array}$} & \multicolumn{8}{|c|}{ CAREER STATUS } \\
\hline & \multicolumn{2}{|c|}{$\begin{array}{l}\text { MASTER } \\
\text { STUDENTS }\end{array}$} & \multicolumn{2}{|c|}{$\begin{array}{l}\text { DOCTORAL } \\
\text { STUDEN TS }\end{array}$} & \multicolumn{2}{|c|}{$\begin{array}{l}\text { UNTENU RED } \\
\text { FACULTYY }\end{array}$} & \multicolumn{2}{|c|}{$\begin{array}{l}\text { TENURED } \\
\text { FACULTY }\end{array}$} \\
\hline & 1979 & 1984 & 1979 & 1984 & 1979 & 1984 & 1979 & 1984 \\
\hline White & 76.0 & 82.0 & 82.0 & 75.3 & 85.8 & 84.3 & 90.1 & 89.6 \\
\hline Asian & 9.2 & 8.8 & 6.3 & 10.9 & 4.8 & 4.7 & 5.1 & 4.8 \\
\hline Bl ack & 7.6 & 3.5 & 5.6 & 4.8 & 4.6 & 4.4 & 2.8 & 2.4 \\
\hline Mex. Am & 2.9 & 3.9 & 5.2 & 6.4 & 2.7 & 4.7 & 0.7 & 1.4 \\
\hline other & 4.3 & 1.8 & $\begin{array}{r}0.9 \\
---\end{array}$ & $\begin{array}{r}2.7 \\
---\end{array}$ & 2.1 & $\begin{array}{r}2.0 \\
----\end{array}$ & 1.3 & 1.8 \\
\hline Total & 100.08 & 100.08 & 100.08 & 100.18 & 100.08 & 100.18 & 100.08 & 100.08 \\
\hline Tota1 N & 801 & 544 & 1215 & 736 & 437 & 299 & 863 & 930 \\
\hline
\end{tabular}

* Race or ethnicity of 46 international students was not identified; they have been excluded from this table.

portional representation of minorities is the result of a legacy of discrimination. We repeat the observation from the initial PSA survey, that "perhaps these findings do, in fact, point in the direction of such practices, but without further investigation into the process by which decisions (are made) to admit graduate students, award them support, hire new faculty, and grant tenure and promotions . . . , how our results came about remains speculative"' (Nigg and Axelrod, 1981: 124).

Certain of the trends revealed in the study are, nonetheless, highly suggestive, and are an appropriate basis for further discussion and deliberation within the profession. One is the direction of changes in representation as graduate enrollment and academic employment have contracted over the last five years. The forward movement of women into higher academic ranks and tenured positions and women's slowly growing share of all faculty positions take on added significance as the total number of academic positions has declined. The relatively unchanged proportion of minorities on faculties might also be taken as a sign 
that the contraction in the field has not occurred at the expense of groups most recently included within the profession. More disturbing are trends among minority groups, with an increasing presence of Asians matched by decreases in black faculty representation.

This study provides no direct evidence about the factors that attract students to graduate programs, or determine their decisions to seek an academic career. The composition of the graduate student body contains the possibilities for the future composition of the faculty, but provides only a dim outline of its ultimate shape. After five years of near- or above parity with men among the ranks of graduate students, women's share of faculty positions has increased only modestly, and stands at less than one-quarter. In contrast, except for Asians the proportions of minority students have remained constant or have declined. Financial support appears to be increasingly critical to graduate students in sociology, and has expanded dramatically among enrolled women and especially minorities. Unfortunately, our data give no indication of the numbers of potential students who have opted for other studies and employment options because of the limited pool of financial assistance. The sharp decrease in the number and proportion of students without financial support is an indication of how critical this assistance may have become in decisions to enter into a sociological career. Among those who ultimately make this decision, it is unclear which categories of students will then choose to seek employment in government or industry, rather than academe, and why they do so.

These uncertainties underscore the need for a continuation and an expansion of research into patterns of inclusion and exclusion within the profession. A periodic census of the sociology departments within the PSA region is essential for monitoring the rate of change in these patterns, but is incomplete. Further analysis of the institutional contexts within which this change occurs is now possible with longitudinal data from 1979 and 1984, but we still lack insights into the departmental and personal decisions that affect student admissions and career decisions, and faculty hiring, tenure, and promotion. 


\section{NOTES}

1. The report is largely restricted to the western United States (Alaska, Arizona, California, Colorado, Hawaii, Idaho, Montana, Nevada, New Mexico, Oregon, Utah, Washington, and Wyoming). Three universities from two western Canadian provinces were included in the 1979 sample, but were excluded in 1984. Some Canadian departments had indicated in 1979 that they were prohibited from releasing the faculty information requested in the survey.

2. The 1984 survey was less restrictive than the 1979 survey in including social science departments that offered sociology courses but not a sociology degree. There were 35 responding departments in the 1984 study that had not been respondents in 1979. Of these additional departments, $89 \%$ had no graduate program and $37 \%$ did not offer a bachelors' degree in sociology, only sociology courses.

3. Departmental chairs were deleted from this analysis because they are often $e x$ officio members of all departmental committees, or are excluded from all such committees. These findings, for 1979 and 1984, can only be interpreted with caution. In 1979, complete information on committee assignments was available for only about half of the faculty. Information for entire departments was not provided in some instances; in others, individual faculty were not enumerated. In 1984, chairs were presented with the option of reporting that they did not know a faculty member's committee responsibilities. Unless "don't know" was checked, blanks were assumed to imply that faculty members had no committee assignments, except in departments larger than five members for which no committee assignments were recorded for any faculty; in the latter case, committee information was considered missing.

4. In the national data, the category "Spanish American" included all Hispanics. For comparability purposes, we have combined our Mexican American and other Hispanic categories. However, in parentheses a category for Mexican American sociologists has been included to determine their representation within the larger category.

5. For this comparison we have excluded the international students in 1984 whose race or ethnicity was unspecified. This group had been excluded from the 1979 enumeration of students with financial support.

\section{REFERENCES}

Blackwell, J. E., M. Jackson, and J. W. Moore

1977 "The status of racial and ethnic minorities." Footnotes, Special Supplement (August).

Hughes, H. M.

1973 The Status of Women in Sociology: 1968-1972. Washington, DC: American Sociological Association.

Jackson, M.

1972 "Minorities and women in sociology: are opportunities changing?" American Sociologist 7.

Nigg, J. and M. Axelrod

1981 "Women and minorities in the PSA region: results of the 1979 survey." Pacific Sociological Review (January). 
Rossi, A.

1970 "Status of women in graduate departments of sociology, 1968-1969." American Sociologist 5: 1-11.

Stephen Kulis is Assistant Professor of Sociology at Arizona State University. His research interests include poverty policy, social support, and family structure. He is currently involved in a study of demoralization and well-being among families affected by AFDC cutbacks.

Karen A. Miller is Associate Professor and Associate Director of the Survey Research Laboratory in the Department of Sociology at Arizona State University. She was formerly a research sociologist at the Laboratory of Socioenvironmental Studies, National Institute of Mental Health. She is currently investigating the career patterns of male and female workers.

Morris Axelrod is Professor of Sociology and Director of the Survey Research Laboratory at Arizona State University. His current research interests are in the areas of ethnogastronomy and survey research methods.

Leonard Gordon is Professor and Chair of the Department of Sociology at Arizona State University. He recently completed a Rockefeller Foundation Bellagio Study Grant on cross-cultural and longitudinal racial and ethnic stereotyping analysis and is cofounder of the Southwestern Urban Studies Basic Research Group, which has initiated omnibus state and metropolitan surveys through the ASU Sociology Survey Research Laboratory. His most recent articles are "The Sociological Expert Witness in a Case of Collective Interracial Violence" in Clinical Sociology Review (1986) and "College Student Stereotypes of Blacks and Jews on Two Campuses: Four Studies Spanning 50 Years" in Sociology and Social Research (1986). 